\title{
INTERRUPTIVE TIME SERIES ANALYSIS OF GST UPON NON-PERFORMING NON-HOUSING PROPERTY LOANS: CASE STUDY FROM MALAYSIA
}

\author{
Tham Kuen-wei ${ }^{1 *}$, Rosli Said ${ }^{2}$ and Yasmin Mohd Adnan ${ }^{3}$ \\ ${ }^{1}$ Centre for Sustainable Urban Planning \& Real Estate, \\ University Malaya, Malaysia. \\ ${ }^{2,3}$ Associate Professor at Centre for Sustainable Urban Planning \& Real Estate, \\ University Malaya, Malaysia.
}

\begin{abstract}
Value Added Taxes increases the cost of living and affect the ability of loan repayments indirectly. The introduction of the Goods and Services Tax (GST) in Malaysia in 2014 had garnered significant attention on its potential negative effects on the property industry. Coincidentally, there is a rise of non-performing non-housing property loans (NPNHLs) consisting of industrial and commercial property loans as GST was introduced and was in effect. The NPNHLs which consists of mainly industrial and commercial property loans faced a steep increase for the first time in 2014, after a long and consistent decline since 2007. From the inception stage of the GST to its effective implementation date, the Malaysian NPNHLs responded with a unique pattern that offers an opportunity for research. Hence, this study aimed to investigate and measure the intervention spill-over effects of GST upon the Malaysian NPNHLs. Utilizing a quasi-experimental design of interruptive time series regression analysis, it was found that there is a close and significant relationship between the implementation of GST and the rise of NPNHLs in Malaysia. The pre and post intervention of the GST regime was found to be in sync with the rise of non-performing non-housing property loans in Malaysia.
\end{abstract}

Keywords: value added tax, goods and services tax, interruptive time series regression, Malaysia

\section{ARTICLE INFO}

Article History:

Received: 21 June 2019

Accepted: 1 March 2021

Published: 30 April 2021

* Corresponding Author: Tham Kuen-wei. E-mail: thamkuenwei@hotmail.com 


\section{INTRODUCTION}

The volatility of oil prices in the global arena had caused the Malaysian government to consider a consumption tax to compensate the loss of government revenue. At the time of planning such implementation, it had been hoped that the tax will help reduce the dependency of the Malaysian government on Petronas, Malaysia's largest crude oil producer. The government is seeking additional revenue to offset its budget deficit and reduce its dependence on revenue from Petronas, Malaysia's state-owned oil company which accounts for almost $30-40 \%$ of the Malaysian government revenue (Lee, 2013). The $6 \%$ tax will replace a sales-and-service tax of between $5-15 \%$. This had resulted in the introduction of the Goods and Services Tax (GST), a consumption tax imposed on the sale of goods and services (Zainal et al., 2016). In Australia and the United Kingdom, it is more commonly known as the Value Added Tax (VAT) (Schenk \& Oldman, 2007). Malaysia had been implementing another type of tax known as the Sales and Services Tax (SST) prior to GST (Zainal et al., 2016). This had been used for several decades until the introduction of GST. SST is a form of indirect taxation imposed on consumers, collected by corporate and business entities with accountability to the Royal Customs and Excise Department and would be imposed on a manufacturer upon sale and importer of taxable goods. The rates are 10\% for all taxable goods; 5\% for fruits, food and building materials; and 20\% for alcoholic drinks (Malaysian GST Act, 2014). The past SST regime is also an indirect tax 5\% imposed on customers who consume food or services in places such as restaurants, hotels, or engaged professional services such as valuation and legal fees. The SST had been implemented in Malaysia for many years, including 2007 to 2015, until the Good and Services Tax replaced it with a 6\% standard rate in April 2015 (Malaysian GST Act, 2014).

\section{LITERATURE REVIEW}

\section{GST and Property}

Under the Malaysian GST Scheme, residential properties are exempted from GST. Residential properties fall under the "Exempt Rated" basket of goods (MOF, 2014). However, commercial properties also known as 
non-residential properties such as offices, industrial factories and even agricultural farms are standard rated. This had caused a huge spike of prices and other problems that may or may not lead to the rise of non-performing non-residential property loans in Malaysia.

Basic building materials such as bricks, cement and floor tiles fall inside the First Schedule Goods. These crucial construction materials are not subjected to the sales tax (GST) (Malaysian GST Act, 2014). Meanwhile, other building materials fall inside the Second Schedule Goods, in which all the goods in this category will only be charged a sales tax of $5 \%$. After GST implementation, all building materials and professional services such as from quantity surveyors, architects, contractors, and civil Engineers will be subject to GST with a standard rate of $6 \%$ (MOF, 2014). This had raise the production cost for developers. In the way how GST works, additional tax costs were simply passed on to the final consumer (Standard-Rated goods), or is claimed back from the government (Zero-Rated goods). But in this case (Exempt-Rated), the additional tax cost is borne by the party before the final consumer which is the developer. The developer does not have a next "victim" in the supply chain. Hence, developers simply absorbed the costs and included such costs in their asking prices. Studies have shown that the prices of properties had increased after the implementation of GST (Zain \& Yusuf, 2017).

Moreover, property outgoing costs such as electricity and water bills will not be subjected to GST (Malaysian GST Act, 2014). All supplies where charges and fees imposed by the Government related to real estate such as quit rent, premium, survey fees (conducted by Survey Department), registration of titles and other payments are regarded as out of scope (MOF, 2014). The assessment rates imposed by the local authorities are also out of scope of GST. Residential Properties would be exempted from GST, but still subject to Real Property Gain Taxes as in status quo (MOF, 2014). To this end, the sale, purchase and rental of properties which are on a commercial and/or industrial title are likely to have GST implications. The sale or leases of commercial buildings were taxed at $6 \%$ while the sale or lease of residential, agricultural and burial land would be exempted from GST (MOF, 2014). The type of real estate would be determined based on its land use and category as stated in its title. Any transfer of the whole right of ownership in land, land under an agreement for the sale of such land, 
land under an agreement which expressly stipulates that the ownership of such land will pass at some time in the future, any interest under Deed of Assignment or any strata title is a supply of goods.

Stratified properties for residential usage such as small office home office (SoHo) and condominiums that were built on commercial land will be taxed for GST, and yet not all purchasers have the opportunity to claim back their GST as the property is supposed to be a residential property, but built on a commercial land. The supply of land used for agricultural, residential (including residential house such as link house, semi-detached house, detached house, apartment including serviced apartment and condominium) or general purpose such as burial, playground and religious is exempt from GST (MOF, 2014). The supply of land and building used for commercial, administrative and industrial purpose such as shop lots, office, retail business, small office home office (SoHo), small office virtual office (SoVo), small office flexible office (SoFo), factories, hotel, motel, inn, hostel and warehouses is subject to GST (MOF, 2014).

\section{Spill Over Effects of GST and NPNHLs}

Value added taxes (VATs) and goods and services taxes (GSTs) are found to possess various spillover effects in affecting NPLs indirectly.

VATs were found to affect mortgage markets in terms of increasing the costs of borrowing, resulting in the reduced ability of loan repayments. In a study conducted in Australia on GST, the implementation of GST was found to lead to a substantial rise in mortgage costs charged by credit unions in the post-GST periods. The research showed that credit unions passed more than twice of the GST rate. This suggests GST over-shifting, and it is generally consistent with tax over-shifting literature (Liu et al., 2014). Based on the study, they found that for every 10 basis point rise in mortgage interest would lead to an increase of A $\$ 1.2$ billion per annum in the borrowers' cost. This research is recent and relevant in Malaysia due the proximity and system of the nature of the Australian GST is extremely similar to Malaysian GST. It shows direct implications to property borrowers. Rising interest rates resulted in the inability of borrowers to repay their loans, which in turn causes a non-performing loan (Zainol et al., 2018; Adebola et al., 2011; Bofondi \& Ropele, 2011). In another study conducted in Europe by the 
European Systemic Risk Board (ESRB), it was found that VAT affects the sale of NPLs to investors as real estate taxes and stamp duties rise, resulting in the increased cost of buying NPLs for investors (ESRB, 2018). VAT may additionally reduce the value of NPLs for non-bank investors, which do not benefit from the exemptions available to banks. For example, VAT charged on loan servicing automatically increases the costs borne by servicers for the administration and collection of NPLs, thus making them less competitive than banks (ESRB, 2017). In the report, they even suggested imposing an exemption on the NPLs.

VAT is also suggested to contribute to NPLs due to cost push inflation in construction prices which makes borrowers face difficulty in repaying their hefty property loans. In a 2013 study conducted at the Bahamas, implementation of VAT was found to affect construction of new houses due to the tax implication (The Nassau Institute, 2013). As costs of construction are high, developers absorb their costs into their sale prices. These costs were found to be the cause of cost push inflation, which makes properties much more expensive, and reduces the cash flow of borrowers as they serve their loans. In another study conducted by (Breen, et al., 2002) in Australia, it was found that building material costs are the major components in construction development costs while GST implementation has been identified to have inflated the construction material prices within a year of implementation. This is similar to the scenario in Malaysia (Zain, et al., 2017). Cost Push Inflation of Construction and Property Prices caused by taxation can be a potential cause of non-performing loans as property prices became expensive as a consequence of rising construction costs (Klein, 2013; Khaled. 2016). Khaled (2016) found that property prices and NPLs are co-integrated in long term periods and high property prices are linked to higher NPLs.

VATs can also cause general inflation as goods become more expensive and in turn reduces the ability of borrowers to meet their debt obligations. An example of such implication would be the value added taxation system which was introduced in the United Arab Emirates. VAT was introduced into United Arab Emirates on 1st of February 2018, with an effective rate of $5 \%$ (UAE, 2018). The implementation of the VAT had caused tremendous concerns and pressure to the citizens and almost half of UAE citizens are concerned that they cannot afford the increased cost of living through VAT which affects the ability of consumers to pay their mortgage expenses. In the 
survey, $63 \%$ of the citizens expected a salary increase to offset the effects of VAT (Albishi et al., 2020). Aside to UAE, VATs have also been found to affect and cause inflation in both high income and low income countries after they are implemented such as France and Nigeria (Gautier \& Lalliard, 2013; Olatunji, 2013). Rising of inflation can directly reduce borrowers' repayment capacity and a main cause of rising NPLs (Klein, 2013).

Another factor to be taken into consideration is that the Tax Compliance Cost rose substantially when GST was implemented in Malaysia. Scholars generally share the same definition and opinion about Tax Compliance Cost (TCC). Sanford (1995) defined TCC as the costs incurred by taxpayers to meet their prescribed obligations under the tax law and regulations other than the actual tax sum while Tran-Nam et al., (2000) stated TCC as the value of resources expended by taxpayers in fulfilling their tax obligations (Tran-Nam et al., 2000). According to Ariff and Pope (2002) TCC is the cost incurred by the taxpayer in meeting the conditions set out in the tax regime (Ariff \& Pope, 2002). This includes the preparation and submission of tax returns in accordance with the tax law of a country. TCC also includes all costs incurred by corporate and private business institutions to comply with tax regulations, excluding the tax itself. Most of these costs are closely related to information processing activities such as record keeping and filing tax returns along with tax data. In all, TCC is actually a separate amount of sum that taxpayer has to bear as part of his preparation to pay the GST to the government. Being the case, TCC could be considered as the secondary or supplementary cost incurred in the tax payment process since the taxpayer has to set-aside a certain amount of money for expenses incurred in meeting or fulfilling their legally mandatory tax obligations (Stanford, 1995). As such, there is a high probability that the amount of TCC would differ greatly between sectors, industries or jurisdictions. In Malaysia, TCC involves engaging of consultants, hiring of new personnel, training of personnel for GST compliance, purchasing of software and restructuring of accounting models that result in higher operational costs, reduction of cash flow and potentially the ability to serve their commercial or industrial property loans (Liu et al., 2014).

The issue of non-performing property loans and rising of recent foreclosures has been an elephant in the room, and caught massive attention from various parties including developers, property consultants, 
academicians, businesses, and general public. This is especially when GST was gazetted into an Act in June 2014. Non-performing non-residential property loans saw a steep rise for the first time in almost a decade, and continued to rise further when GST was effective in 2015 (Bank Negara Malaysia, 2018). Moreover, the spending power of consumers had been found to be reducing after the implementation of GST, which may affect the ability of loan repayments (Zain, et al., 2017). Taxation can also impact cash flow which disrupts the operations of an entity including corporations (Abdul Rahman et al., 2018).

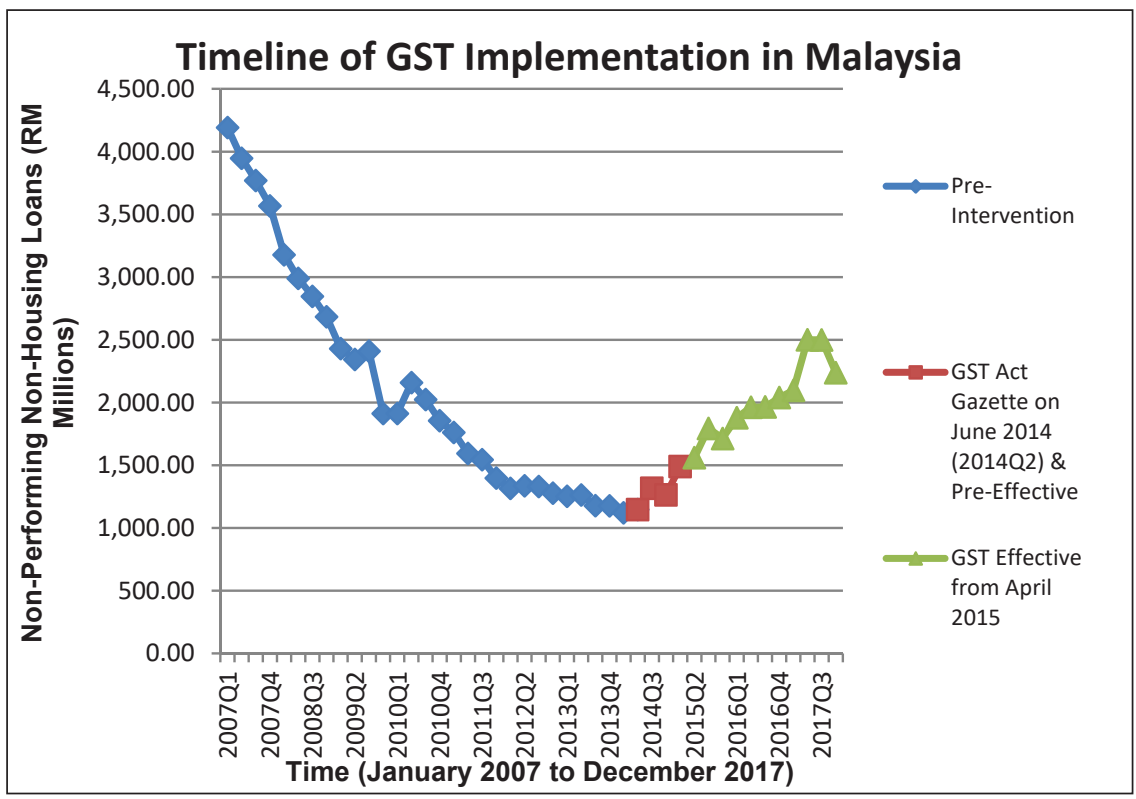

Figure 1: Non-Performing Non-Housing Loans

in Relate to The Time of GST Implementation in Malaysia

Source: Compiled by Author based on Data from Bank Negara Malaysia (1997-2018).

As shown on Figure 1 above, non-performing non-housing property loans increased for the first time in the second quarter of 2014, despite facing almost a decade of decline since 2007. Coincidentally, the GST Act 2014 was gazetted in June 2014. This provided an opportunity for research on the potential impact of the intervention of GST taxation on non-residential property NPLs which includes industrial and commercial properties. 
There are very few studies in Malaysia on the relationship between GST and non-performing property loans specifically for non-residential properties, which are not under the GST list of exempt goods nor the zero rated list as these properties are standard rated. Many stakeholders are very concerned about this issue as all interests are at stake. The increasing attention on non-performing property loans has called upon researchers to explore it in order to provide an insight into this issue. Hence, this study aimed to see the potential intervention effects of GST on NPLs which can be helpful for strategic monetary policy makers in understanding the potential effects of GST on non-housing NPLs in Malaysia.

\section{RESEARCH DESIGN AND METHODOLOGY}

The approach in this study is experimental in nature while the technique involved is the quasi-experimental design of interruptive time series regression (ARIMA) to study the relationship between the spillover effects of Goods and Services Tax implemented in 2014 upon non-performing nonhousing property loans in Malaysia. ARIMA is very suitable in analyzing GST and non-performing non-housing property loans due to the complexity of the taxation regime where it is difficult to quantify its "indirect and spillover effects" which makes it difficult to link taxation as the real cause of non-performing non-housing property loans. Instead, ARIMA works perfectly to evaluate the longitudinal effects of GST intervention, through regression modeling.

ARIMA models are, in theory, the most general class of models for forecasting a time series which can be made to be "stationary" by differencing in conjunction with nonlinear transformations such as logging or deflating. A random variable that is a time series is stationary if its statistical properties are all constant over time. A stationary series has no trend, its variations around its mean have constant amplitude, and it wiggles in a consistent fashion, i.e., its short-term random time patterns always look the same in a statistical sense. The latter condition means that its autocorrelations (correlations with its own prior deviations from the mean) remain constant over time, or equivalently, that its power spectrum remains constant over time. A random variable of this form can be viewed as a combination of signal and noise, and the signal (if one is apparent) 
could be a pattern of fast or slow mean reversion, or sinusoidal oscillation, or rapid alternation in sign, and it could also have a seasonal component. An ARIMA model can be viewed as a "filter" that tries to separate the signal from the noise, and the signal is then extrapolated into the future to obtain forecasts. The ARIMA forecasting equation for a stationary time series is a linear equation in which the predictors consist of lags of the dependent variable and/or lags of the forecast errors.

The general equation in ARIMA in its general linear form is:

$$
\mathrm{Yt}=\mu+\phi 1 \mathrm{Yt}-1
$$

Where $\boldsymbol{Y t}$ is regressed on itself lagged by one period. This is an "ARIMA $(1,0,0)+$ constant" model. If the mean of $\boldsymbol{Y t}$ is zero, then the constant term would not be included.

In this case, the forecasting equation in this case is:

$$
\text { NPLt }=\mu+\phi 1 \text { NPLt-1 }
$$

Where NPLt is regressed on itself lagged by one period. In this form, the interruptive time series is modeled using a linear regression model, whose regression coefficients estimate the pre-intervention slope, the change in level at the intervention points, and the change in slope from preintervention to post intervention points $(t)$. The level change is an estimate of the change in level that can be attributed to the intervention, between the time points immediately before, and immediately after the intervention, and accounting for the pre-intervention trend. The change in slope quantifies the difference between the pre-intervention and post intervention slopes.

Several points of interest were identified, which is Post3; 3 quarters after the implementation of GST, Post $6 ; 6$ quarters after the Implementation of GST, and Post10; 10 quarters after the implementation of GST. This can be seen as follows: 
Table 1: Observation Points in ARIMA from GST Pre-Effective Period

\begin{tabular}{cl} 
Prefix in SPSS & \multicolumn{1}{c}{ Note } \\
\hline Level & $\begin{array}{l}\text { Pre-Intervention Point (Referring to April 2014Q2). } \\
\text { Immediate Period before Post3 (2014Q2 (June 2014) -After } \\
\text { Gazette of the GST Act, but before being effective) }\end{array}$ \\
Post3 & $\begin{array}{l}\text { 3 Quarters or 9 months after the Implementation of GST } \\
\text { (Effective and in force, 2015Q1, April 2015) } \\
\text { Immediate Period before Post6 }\end{array}$ \\
Pre6 & $\begin{array}{l}\text { 6 Quarters or 18 months after the Implementation of GST } \\
\text { Post6 }\end{array}$ \\
Pre10 & 10 Quarters or 30 months after the Implementation of GST \\
Post10 &
\end{tabular}

These points of interest examined in detail the NPL for non-residential properties in Malaysia, mainly commercial and industrial properties' loans in short, medium and long term effects, ranging from 9 months, 18 months and 30 months respectively in its prediction from the point of intervention, i.e the date GST becomes fully effective in order to measure the potential spill- over effects of GST on non-performing industrial and commercial property loans in Malaysia. Hence, this study will offer a unique insight into the implications of GST on non-performing non-residential property loans in Malaysia which covers both commercial and industrial properties.

\section{EMPIRICAL RESULTS}

\section{Pre-slope Analysis}

The following show the results for the First Model with NPNHL (Outcome) as the Dependent Variable, with Phase, Period and Interact as the Independent Variables. The purpose of this model is to show the difference between slopes (Interact) and the pre-slope (Periods). 
Table 2: ARIMA Model Parameters of First Model Dependent Variable (Outcome), Independent Variable (Phase, Period, Interact)

\begin{tabular}{|c|c|c|c|c|c|c|c|}
\hline & & & & Estimate & SE & $t$ & Sig. \\
\hline \multirow{5}{*}{$\begin{array}{l}\text { OUTCOME- } \\
\text { Model_1 }\end{array}$} & \multirow{2}{*}{ OUTCOME } & Constant & & 3888.561 & 606.427 & 6.412 & .000 \\
\hline & & AR & Lag 1 & .953 & .074 & 12.945 & .000 \\
\hline & PERIOD & Numerator & Lag 0 & -79.614 & 33.821 & -2.354 & .024 \\
\hline & PHASE & Numerator & $\operatorname{Lag} 0$ & -4675.249 & 3173.814 & -1.473 & .149 \\
\hline & INTERACT & Numerator & Lag 0 & 143.054 & 92.569 & 1.545 & .130 \\
\hline
\end{tabular}

The values of the pre-slope, or the pre-intervention slope of the

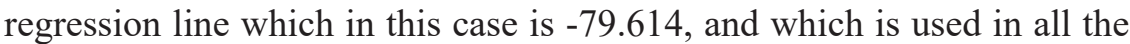
subsequent analyses of the different time points (to take into account the already existing trend in the data when calculating the intervention effects), The pre-slope tells us that before the intervention there was a decrease of RM 79,614,000 (RM 79.613 Millions) non-performing property loans ( $\mathrm{P}=0.024)$.

The coefficient for 'phase' (-4675.249) in the first part of the model is discarded in this type of analysis- it represents the point on the y-axis when projecting back the line for the post-slope to the $\mathrm{y}$-axis (where $\mathrm{x}=0$ ), which adds nothing of value for the analysis.

The coefficient for 'interact' (143.054) is the difference between the pre-slope and the post-slope, with $\mathrm{P}=0.130$. When adding the pre-slope $(-79.614)$ and the interact (143.054) we get the post-slope of $(-79.614$ $+143.054=63.592)$, which also is used in all the next analyses of the following time-points.

\section{Pre and Post 3 Quarters Intervention}

The following show the results for the Second Model with NPNHL (Outcome) as the Dependent Variable, with Phase, Period and Interact as the Independent Variables. The purpose of this model is to show the difference between slopes (Interact) and the pre-slope (Periods). Here the level effect (Phase), standard error and p-value and for the level effect are presented for a slope at pre and post 3 quarters intervention. 
Table 3: ARIMA Model Parameters of Second Model at Pre and Post 3Q Dependent Variable (Outcome), Independent Variable

(Phase, Period, Interact)

\begin{tabular}{clllcccc}
\hline & & & & Estimate & SE & t & Sig. \\
\hline \multirow{2}{*}{ OUTCOME } & Constant & & 3879.582 & 620.578 & 6.252 & .000 \\
& & AR & Lag 1 & .954 & .074 & 12.924 & .000 \\
$\begin{array}{c}\text { OUTCOME- } \\
\text { Model_1 }\end{array}$ & PHASE & Numerator & Lag 0 & 536.156 & 282.170 & 1.900 & .065 \\
& PRE3 & Numerator & Lag 0 & -79.155 & 34.403 & -2.301 & .027 \\
& POST3 & Numerator & Lag 0 & 63.592 & 66.662 & .954 & .346 \\
\hline
\end{tabular}

The 'Phase' is here the 3 month level effect $=536.156$, an increase of RM 546.156 million of non-performing property loans per quarter (the direct intervention effect $)(\mathrm{P}=0.065)$.

\section{Pre and Post 6 Quarters Intervention}

The following show the results for the Second Model with NPNHL (Outcome) as the Dependent Variable, with Phase, Period and Interact as the Independent Variables. The purpose of this model is to show the difference between slopes (Interact) and the pre-slope (Periods). Here the level effect (Phase), standard error and p-value and for the level effect are presented for a slope at pre and post 6 quarters intervention.

Table 4: ARIMA Model Parameters of Second Model at Pre and Post 6Q Dependent Variable (Outcome), Independent Variable (Phase, Period, Interact)

\begin{tabular}{clllcccc}
\hline & & & & Estimate & SE & t & Sig. \\
\hline \multirow{2}{*}{ OUTCOME } & Constant & & 3886.902 & 608.564 & 6.387 & .000 \\
& AR & Lag 1 & .953 & .074 & 12.946 & .000 \\
$\begin{array}{c}\text { OUTCOME- } \\
\text { Model_1 }\end{array}$ & PHASE & Numerator & Lag 0 & 971.773 & 531.706 & 1.828 & .075 \\
& PRE6 & Numerator & Lag 0 & -79.679 & 33.815 & -2.356 & .024 \\
& POST6 & Numerator & Lag 0 & 64.332 & 66.813 & .963 & .342 \\
\hline
\end{tabular}

The 'Phase' is here the 6 month level effect $=971.773$, an increase of RM 971.773 million of non-performing property loans per quarter (the direct intervention effect) $(\mathrm{P}=0.075)$. 


\section{Pre and Post 10 Quarters Intervention}

The following show the results for the Second Model with NPNHL (Outcome) as the Dependent Variable, with Phase, Period and Interact as the Independent Variables. The purpose of this model is to show the difference between slopes (Interact) and the pre-slope (Periods). Here the level effect (Phase), standard error and p-value and for the level effect are presented for a slope at pre and post 10 quarters intervention.

Table 5: ARIMA Model Parameters of Second Model at Pre and Post 10Q Dependent Variable (Outcome), Independent Variable

(Phase, Period, Interact)

\begin{tabular}{|c|c|c|c|c|c|c|c|}
\hline & & & & Estimate & SE & $\mathbf{t}$ & Sig. \\
\hline \multirow{6}{*}{$\begin{array}{l}\text { OUTCOME- } \\
\text { Model_1 }\end{array}$} & \multirow{3}{*}{ OUTCOME } & Constant & & 3887.462 & 617.073 & 6.300 & .000 \\
\hline & & AR & Laq 1 & 954 & .074 & 12.949 & .000 \\
\hline & & & & & & & \\
\hline & PHASE & Numerator & Lag 0 & 1546.227 & 892.096 & 1.733 & .091 \\
\hline & PRE10 & Numerator & Lag 0 & -79.608 & 34.205 & -2.327 & .025 \\
\hline & POST10 & Numerator & Lag 0 & 64.242 & 66.756 & .962 & .342 \\
\hline
\end{tabular}

The 'Phase' is here the 10 month level effect $=1546.227$, an increase of RM 1.546227 Billion of non-performing property loans per quarter (the direct intervention effect $)(\mathrm{P}=0.091)$.

\section{Confidence Intervals}

The results reported in the output from the analysis do not directly give us the confidence intervals around the estimated effects. But based on estimates of effects and the standard error (SE) of the estimates of effect, confidence intervals can be calculated. The SE's are found in the same tables as the estimates of effect.

For the calculation of confidence intervals we need the two-tailed 2.5 percentile from the t-distribution with (the number of observations minus 5) degrees of freedom (df); in our example 13-5=8. This can easily be calculated in Excel using the formula tinv $(0.05 ; 8)$ which equals 2.306 . 
The confidence interval can now be calculated using the formula:

$$
\text { Estimate of Effect +/ - TINV }(0.05,8) \text { XSE }
$$

Based on the above formula, we obtained the following results for 3,6 and 10 quarters confidence intervals.

$$
\begin{gathered}
\text { Estimate of Effect }+/-\boldsymbol{T I N V}(\mathbf{0 . 0 5}, \boldsymbol{8}) \boldsymbol{X} \boldsymbol{S E} \\
\text { Lower }=536.156-2.306(282.170)=-32.529 \\
\text { Upper }=536.156+2.306(282.170)=1104.841
\end{gathered}
$$

3 Quarters; Estimate of effect: 536.156; SE: 282.170; 95\% Confidence intervals: 32.529 to 1104.841 .

$$
\begin{gathered}
\text { Estimate of Effect }+/-\boldsymbol{T I N V}(\mathbf{0 . 0 5}, \boldsymbol{8}) \boldsymbol{X ~ S E} \\
\text { Lower }=971.773-2.306(531.706)=-99.827 \\
\text { Upper }=971.773+2.306(531.706)=2043.373
\end{gathered}
$$

6 Quarters; Estimate of effect: 971.773; SE: 531.706; 95\% Confidence intervals: 99.827 to 2043.373

$$
\begin{aligned}
& \text { Estimate of Effect }+/-\boldsymbol{T I N} \boldsymbol{V}(\mathbf{0 . 0 5}, \boldsymbol{8}) \boldsymbol{X} \boldsymbol{S E} \\
& \text { Lower }=1546.227-2.306(892.096)=-251.703 \\
& \text { Upper }=1546.227+2.306(892.096)=3344.157
\end{aligned}
$$

10 Quarters; Estimate of effect: 1546.227; SE: 892.096; 95\% Confidence intervals: 251.703 to 3344.157 
Table 6: Summary of Confidence Intervals for 3,6 and 10 Quarters in the ARIMA respectfully

\begin{tabular}{lcccccc}
\hline & \multicolumn{3}{c}{ Phase Level } & & \multicolumn{2}{c}{ Confidence Intervals } \\
\cline { 2 - 3 } & $\begin{array}{c}\text { Co-efficient of } \\
\text { Phase }\end{array}$ & P Value & $\begin{array}{c}\text { Standard } \\
\text { Error }\end{array}$ & & Lower & Upper \\
\hline $\begin{array}{l}3 \text { Quarters } \\
\text { (9 Months) }\end{array}$ & 536.156 & 0.065 & 282.170 & & -32.5294 & 1104.841 \\
$\begin{array}{l}\text { 6 Quarters } \\
(18 \text { Months })\end{array}$ & 971.773 & 0.075 & 531.706 & & -99.8273 & 2043.373 \\
$\begin{array}{l}10 \text { Quarters } \\
(30 \text { Months })\end{array}$ & 1546.227 & 0.091 & 892.096 & & -251.703 & 3344.157 \\
& & & & & \\
\hline
\end{tabular}

In summary, the coefficient of phase for all 3,6 and 10 Quarters fell within the appropriate confidence intervals. The models formed are high and accurate in its predictive value.

\section{DISCUSSION AND CONCLUSION}

Beginning at RM 4.1928 Billion non-performing property loans in the first quarter of 2007 (the first quarter for which data were available for this analysis), the number of non-performing property loans decreased by RM 79.614 Million per quarter prior to the intervention (at the end of the first quarter of 2015). When this trend is taken into account in the Interruptive Time Series analysis, it is uncertain what, if any impact the implementation of Goods and Services Tax had on non-performing property loans. The point estimate suggests that the implementation of Goods and Services Tax may have had a short term effect (reversion to increment of non-performing property loans of RM 546.156 million of non-performing property within 9 months immediately following the intervention).

At the middle term of within 18 months of implementation, the point estimate suggests that the implementation of Goods and Services Tax may have had a mid-term effect increment of RM 971.773 million of non-performing property loans. At a longer term of 30 months suggest the implementation of Goods and Services Tax may affect non-performing property loans a further increase of of RM 1.546227 Billion of nonperforming property loans. 
While the quasi-experiment model utilizing regression analysis showed a large increment of total non-performing non-housing loans in Malaysia after the implementation of the Goods and Services Tax (GST), trend analysis also showed some convincing results as well. The total nonperforming non-housing loans increased by $58.67 \%$ after the Good and Services Tax was gazetted from the Second Quarter of 2014, until the last of the data in this study which is Quarter 4 of 2017, throughout a period of 15 quarters, or 45 months.

On the other hand, before the Good and Services Tax was gazetted, the total non-performing non-housing loans had seen a gradual decline of $140.13 \%$ throughout a period of 28 quarters, from the first Quarter of 2007 until the First Quarter of 2014, right before the Goods and Services Act 2014 was gazetted.

In both ways, the Goods and Services Tax in Malaysia should be taken into consideration as a potential variable that affects the total nonperforming non-housing loans in Malaysia. Despite the lack of data that shows how corporations or business entities would react to GST that may or may not result in the inability to repay their loans, the impact of Taxes should be given serious attention. This is crucial for a healthy real estate market in Malaysia.

The concept of taking credit for the taxes paid previously to settle the final tax liability of a business was new to Malaysia when GST was introduced in April 2015. All this was confusing for small taxpayers. Malaysia's GST was also applicable to many mass-use items - the tax was blamed by the public for rising prices. Additionally, the country was hit by the multi-year fall in oil prices from the second quarter of 2015, and currency depreciation added to the government's fiscal woes.

The cost of compliance is also high and another factor that may had contributed to such increase. Business owners and corporate entities are required to engage consultants, accountants, purchase software, hiring of new personnel, and other costs of compliance that will undoubtedly increase company expenditure while reducing cash flow that affects the inability to serve their commercial, industrial or other non-housing property loans. 
The goods and services taxes showed significant and high afflictions upon total non-performing non-housing loans in Malaysia in both trend analysis and the quasi-experiment design results.

While the results of this design is limited due to the targeted analysis of GST and non-performing non-housing loans, other factors such as income levels and interest rates can be incorporated in future research. Nonetheless, this paper had found that there are significant potential spillover effects of GST implementation in affecting non-performing non-housing loans as shown by the interruptive time series regression analysis. Despite the Goods and Services Tax being abolished in 2018 (being zero rated), the government and policy makers should make proper consideration when it comes to the new Sales and Services Tax due to similar tax mechanisms between the two. This research had helped policy makers understand the impact of GST on non-performing non-housing loans in Malaysia. Steps should be taken by the government to ensure that the risks are properly compensated by other stimulus packages that would help boost consumers and corporations to repay their non-housing property loans.

\section{REFERENCES}

Abdul Rahman, R., Mahmud, N., Zaini, N., \& Meor Zawawi, M. (2018). Government-linked investment companies' shareholdings and tax aggressiveness. Asia-Pacific Management Accounting Journal, 13(3), 149-166.

Adebola, S. S., Wan Yusoff, W. S. B., \& Dahalan, J. (2011). An ARDL approach to the determinants of nonperforming loans in Islamic banking system in Malaysia. Kuwait Journal of Arabian Journal of Business Management and Review, 1(2), 20-30.

Albishi, G. A., Alghamdi, B., AlSubaie, L., Almohareb., M., Al-Hamoudi, H., ALakeel, H., \& Alshabanah, M. (2020). The value-added tax (VAT): Effects on Saudi economy in the light of The Saudi Vision 2030. International Journal of Scientific Research in Science and Technology, $7(2), 201-214$. 
Ariff, M., \& Pope, J. (2002). Taxation and compliance costs in Asia Pacific economies. Sintok: Universiti Utara Malaysia Press.

Bank Negara Malaysia. (1997-2018). Monthly bulletin reports. Kuala Lumpur: Central Bank of Malaysia.

Bofondi, M., \& Ropele, T. (2011). Macroeconomic determinants of bad loans: Evidence from Italian banks (Working Paper No 89). Bank of Italy Occasional Paper. Retrieved from https://www.bancaditalia.it/ pubblicazioni/qef/2011-0089/QEF_89.pdf

Breen, J., Bergin-Seers, S., Roberts, I., \& Sims, R. (2002). The impact of the introduction of the GST on small business in Australia. Asian Review of Accounting, 10(1), 89-104.

European Systemic Risk Board (ESRB). (2017). Resolving Non-Performing Loans in Europe. Retrieved from European Systemic Risk Board website: https://www.esrb.europa.eu/pub/pdf/reports/20170711_ resolving_npl_report.en.pdf?e4c478e9cabf35b6dec49a064f01c6ed

European Systemic Risk Board (ESRB). (2018). Macroprudential provisions, measures and instruments for insurance. Retrieved from European Systemic Risk Board website: https://www.esrb.europa.eu/ news/pr/date/2018/html/esrb.pr181126.en.html

Gautier, E., \& Lalliard, A. (2013). How do VAT changes affect inflation in France?. Quarterly selection of articles - Bulletin de la Banque de France, (32), 5-27.

Khaled, F. (2016). Credit default and the real estate market. London, UK: Brunel University.

Klein, N. (2013). Non-performing loans in CESEE: Determinants and impact on macroeconomic performance (WP/13/72). Retrieved from International Monetary Fund website: https://www.imf. org/en/Publications/WP/Issues/2016/12/31/Non-PerformingLoans-in-CESEE-Determinants-and-Impact-on-MacroeconomicPerformance-40413 
Lee, E. T. H. (2013). Scope for improvement: Malaysia's oil and gas sector. Research for Social Advancement. Retrieved from https://refsa.org/ wp-content/uploads/2020/10/pdfslide.net_og-scoping-report-malaysiafinal-20130701-compressed.pdf

Liu, B., Huang, A., \& Freudenberg, B. (2014). The impact of the GST on mortgage pricing of Australian credit unions: An empirical analysis. Accounting Research Journal, 27(1), 37-51.

Malaysian GST Act (2014). Attorney General's Chambers of Malaysia.

Ministry of Finance (MOF). (2014). Handbook for goods and services $\operatorname{tax}(G S T)$ for business. Department of Customs Malaysia, Ministry of Finance.

Olatunji, O. C. (2013). Value added tax (VAT) and inflation in Nigeria (1990 to 2003). Asian Journal of Humanities and Social Sciences, 1(1), 123-135.

Sandford, C. (1995). The rise and rise of tax compliance costs. In C. Sandford (Ed.), Tax compliance costs measurement and policy. The Institute for Fiscal Studies, Bath, UK: Fiscal Publications.

Schenk, A., \& Oldman, O. (2007). Value added tax: A comparative approach. Cambridge: Cambridge University Press.

The Government of United Arab Emirates (UAE). (2018). Value added tax of the UAE. Retrieved from https://government.ae/en/information-andservices/finance-and-investment/taxation/valueaddedtaxvat

The Nassau Institute. (2013). The Nassau Institute Report Issue 2013. Retrieved from The Economic Consequences of the Value-Added: http:// www.nassauinstitute.org/files/VATEconomicConsequencesBahamas. pdf

Tran-Nam, B., Evans, C., Walpole, M., \& Ritchie, K. (2000). Tax compliance costs: Research methodology and empirical evidence from Australia. National Tax Journal, 229-252. 
Zain, H. M., \& Yusof, N. A. M. (2017). GST and the influencing factors of prices hikes in daily and consumable goods after the implementation of GST. Journal of Science, Technology and Innovation Policy, 3(2), 13-22.

Zainal, R., Teoh, C. T., \& Yeo, S. P. (2016). The effects of GST (goods and services tax) on construction capital costs and housing property prices. In B. Mohamad (Ed.), European Proceedings of Social \& Behavioural Sciences (pp. 349-354).

Zainol, J. M., Nor, A. M., Ibrahim, S. N., \& Daud, S. (2018). Macroeconomics determinants of non-performing loans in Malaysia: An ARDL approach. International Journal of Academic Research in Business and Social Sciences, 8(10), 692-706. 


\section{APPENDICES}

Appendix 1: Time Periods of Pre and Post Interventions

\begin{tabular}{|c|c|c|c|}
\hline Date & $\begin{array}{c}\text { NPHL (RM } \\
\text { Millions) }\end{array}$ & $\begin{array}{l}\text { NPNHL (RM } \\
\text { Millions) }\end{array}$ & Time Periods \\
\hline 2007Q1 & $14,232.8$ & $4,192.8$ & Pre intervention \\
\hline 2007Q2 & $13,734.4$ & $3,948.1$ & Pre intervention \\
\hline 2007Q3 & $12,702.5$ & $3,771.1$ & Pre intervention \\
\hline 2007Q4 & $12,164.3$ & $3,568.8$ & Pre intervention \\
\hline $2008 Q 1$ & $11,737.5$ & $3,178.5$ & Pre intervention \\
\hline $2008 Q 2$ & $10,838.8$ & $2,990.4$ & Pre intervention \\
\hline $2008 Q 3$ & $10,492.9$ & $2,847.9$ & Pre intervention \\
\hline $2008 Q 4$ & $10,736.2$ & $2,684.0$ & Pre intervention \\
\hline 2009Q1 & $10,878.3$ & $2,431.2$ & Pre intervention \\
\hline 2009Q2 & $10,620.1$ & $2,345.0$ & Pre intervention \\
\hline $2009 Q 3$ & $10,311.7$ & $2,410.5$ & Pre intervention \\
\hline $2009 Q 4$ & $8,923.2$ & $1,913.4$ & Pre intervention \\
\hline $2010 Q 1$ & $8,064.3$ & $1,913.3$ & Pre intervention \\
\hline 2010Q2 & $7,850.8$ & $2,160.4$ & Pre intervention \\
\hline 2010Q3 & $7,793.0$ & $2,025.4$ & Pre intervention \\
\hline $2010 Q 4$ & $7,722.0$ & $1,856.6$ & Pre intervention \\
\hline 2011Q1 & $7,387.2$ & $1,762.3$ & Pre intervention \\
\hline 2011Q2 & $6,905.3$ & $1,596.1$ & Pre intervention \\
\hline 2011Q3 & $6,741.8$ & $1,545.6$ & Pre intervention \\
\hline 2011Q4 & $6,432.3$ & $1,398.5$ & Pre intervention \\
\hline $2012 Q 1$ & $6,330.9$ & $1,317.3$ & Pre intervention \\
\hline $2012 Q 2$ & $5,964.4$ & $1,337.7$ & Pre intervention \\
\hline 2012Q3 & $5,833.7$ & $1,331.1$ & Pre intervention \\
\hline 2012Q4 & $5,658.5$ & $1,278.9$ & Pre intervention \\
\hline $2013 Q 1$ & $5,524.4$ & $1,254.1$ & Pre intervention \\
\hline $2013 Q 2$ & $5,498.2$ & $1,263.4$ & Pre intervention \\
\hline $2013 Q 3$ & $5,445.1$ & $1,179.2$ & Pre intervention \\
\hline $2013 Q 4$ & $5,270.5$ & $1,177.0$ & Pre intervention \\
\hline 2014Q1 & $5,130.3$ & $1,122.1$ & Pre intervention \\
\hline 2014Q2 & $5,201.6$ & $1,148.8$ & GST Act Gazetted in June 2014 \\
\hline $2014 Q 3$ & $4,980.6$ & $1,319.0$ & Pre intervention \\
\hline $2014 Q 4$ & $5,006.0$ & $1,265.6$ & Pre intervention \\
\hline $2015 Q 1$ & $5,054.1$ & $1,491.3$ & Pre intervention \\
\hline 2015Q2 & $5,052.3$ & $1,561.8$ & GST Started \& effective April 2015 \\
\hline $2015 Q 3$ & $5,154.9$ & $1,794.9$ & 3 months post intervention \\
\hline $2015 Q 4$ & $5,025.3$ & $1,714.5$ & 6 months post intervention \\
\hline
\end{tabular}




\begin{tabular}{|l|l|l|c|}
\hline 2016Q1 & $5,041.4$ & $1,879.4$ & 9 months post intervention (Post 3q) \\
\hline 2016Q2 & $5,103.1$ & $1,962.7$ & 12 months post intervention \\
\hline 2016Q3 & $5,306.1$ & $1,966.1$ & 15 months post intervention \\
\hline 2016Q4 & $5,435.6$ & $2,040.3$ & 18 months post intervention (Post 6q) \\
\hline 2017Q1 & $5,557.5$ & $2,098.2$ & 21 months post intervention \\
\hline 2017Q2 & $5,590.0$ & $2,500.7$ & 24 months post intervention \\
\hline 2017Q3 & $5,698.6$ & $2,499.9$ & 27 months post intervention \\
\hline 2017Q4 & $5,425.0$ & $2,238.6$ & 30 months post intervention (Post 10q) \\
\hline
\end{tabular}




\section{APPENDIX 2: INPUTS OF PRE AND POST INTERVENTIONS}

\begin{tabular}{|c|c|c|c|c|c|c|c|c|c|c|}
\hline $\begin{array}{l}\text { Intervention } \\
\text { Time }\end{array}$ & $\begin{array}{l}\text { Outcome } \\
\text { (NPNHL) }\end{array}$ & Period & Phase & Interact & $\begin{array}{c}\text { Pre } \\
3\end{array}$ & $\begin{array}{c}\text { Pre } \\
6\end{array}$ & $\begin{array}{c}\text { Pre } \\
10\end{array}$ & $\begin{array}{c}\text { Post } \\
3\end{array}$ & $\begin{array}{l}\text { Post } \\
6\end{array}$ & $\begin{array}{c}\text { Post } \\
10\end{array}$ \\
\hline-33.00 & $4,192.80$ & 1 & 0 & 0 & 1 & 1 & 1 & 0 & 0 & 0 \\
\hline-32.00 & $3,948.10$ & 2 & 0 & 0 & 2 & 2 & 2 & 0 & 0 & 0 \\
\hline-31.00 & $3,771.10$ & 3 & 0 & 0 & 3 & 3 & 3 & 0 & 0 & 0 \\
\hline-30.00 & $3,568.80$ & 4 & 0 & 0 & 4 & 4 & 4 & 0 & 0 & 0 \\
\hline-29.00 & $3,178.50$ & 5 & 0 & 0 & 5 & 5 & 5 & 0 & 0 & 0 \\
\hline-28.00 & $2,990.40$ & 6 & 0 & 0 & 6 & 6 & 6 & 0 & 0 & 0 \\
\hline-27.00 & $2,847.90$ & 7 & 0 & 0 & 7 & 7 & 7 & 0 & 0 & 0 \\
\hline-26.00 & $2,684.00$ & 8 & 0 & 0 & 8 & 8 & 8 & 0 & 0 & 0 \\
\hline-25.00 & $2,431.20$ & 9 & 0 & 0 & 9 & 9 & 9 & 0 & 0 & 0 \\
\hline-24.00 & $2,345.00$ & 10 & 0 & 0 & 10 & 10 & 10 & 0 & 0 & 0 \\
\hline-23.00 & $2,410.50$ & 11 & 0 & 0 & 11 & 11 & 11 & 0 & 0 & 0 \\
\hline-22.00 & $1,913.40$ & 12 & 0 & 0 & 12 & 12 & 12 & 0 & 0 & 0 \\
\hline-21.00 & $1,913.30$ & 13 & 0 & 0 & 13 & 13 & 13 & 0 & 0 & 0 \\
\hline-20.00 & $2,160.40$ & 14 & 0 & 0 & 14 & 14 & 14 & 0 & 0 & 0 \\
\hline-19.00 & $2,025.40$ & 15 & 0 & 0 & 15 & 15 & 15 & 0 & 0 & 0 \\
\hline-18.00 & $1,856.60$ & 16 & 0 & 0 & 16 & 16 & 16 & 0 & 0 & 0 \\
\hline-17.00 & $1,762.30$ & 17 & 0 & 0 & 17 & 17 & 17 & 0 & 0 & 0 \\
\hline-16.00 & $1,596.10$ & 18 & 0 & 0 & 18 & 18 & 18 & 0 & 0 & 0 \\
\hline-15.00 & $1,545.60$ & 19 & 0 & 0 & 19 & 19 & 19 & 0 & 0 & 0 \\
\hline-14.00 & $1,398.50$ & 20 & 0 & 0 & 20 & 20 & 20 & 0 & 0 & 0 \\
\hline-13.00 & $1,317.30$ & 21 & 0 & 0 & 21 & 21 & 21 & 0 & 0 & 0 \\
\hline-12.00 & $1,337.70$ & 22 & 0 & 0 & 22 & 22 & 22 & 0 & 0 & 0 \\
\hline-11.00 & $1,331.10$ & 23 & 0 & 0 & 23 & 23 & 23 & 0 & 0 & 0 \\
\hline-10.00 & $1,278.90$ & 24 & 0 & 0 & 24 & 24 & 24 & 0 & 0 & 0 \\
\hline-9.00 & $1,254.10$ & 25 & 0 & 0 & 25 & 25 & 25 & 0 & 0 & 0 \\
\hline-8.00 & $1,263.40$ & 26 & 0 & 0 & 26 & 26 & 26 & 0 & 0 & 0 \\
\hline-7.00 & $1,179.20$ & 27 & 0 & 0 & 27 & 27 & 27 & 0 & 0 & 0 \\
\hline-6.00 & $1,177.00$ & 28 & 0 & 0 & 28 & 28 & 28 & 0 & 0 & 0 \\
\hline-5.00 & $1,122.10$ & 29 & 0 & 0 & 29 & 29 & 29 & 0 & 0 & 0 \\
\hline-4.00 & $1,148.80$ & 30 & 0 & 0 & 30 & 30 & 30 & 0 & 0 & 0 \\
\hline-3.00 & $1,319.00$ & 31 & 0 & 0 & 31 & 31 & 31 & 0 & 0 & 0 \\
\hline-2.00 & $1,265.60$ & 32 & 0 & 0 & 32 & 32 & 32 & 0 & 0 & 0 \\
\hline-1.00 & $1,491.30$ & 33 & 0 & 0 & 33 & 33 & 33 & 0 & 0 & 0 \\
\hline 0.00 & $1,561.80$ & 34 & 0 & 0 & 34 & 34 & 34 & 0 & 0 & 0 \\
\hline 1.00 & $1,794.90$ & 35 & 1 & 35 & 36 & 39 & 43 & -2 & -5 & -9 \\
\hline 2.00 & $1,714.50$ & 36 & 1 & 36 & 36 & 39 & 43 & -1 & -4 & -8 \\
\hline 3.00 & $1,879.40$ & 37 & 1 & 37 & 36 & 39 & 43 & 0 & -3 & -7 \\
\hline 4.00 & $1,962.70$ & 38 & 1 & 38 & 36 & 39 & 43 & 1 & -2 & -6 \\
\hline
\end{tabular}


Asia-Pacific Management Accounting Journal, Volume 16 Issue 1

\begin{tabular}{|c|c|c|c|c|c|c|c|c|c|c|}
\hline 5.00 & $1,966.10$ & 39 & 1 & 39 & 36 & 39 & 43 & 2 & -1 & -5 \\
\hline 6.00 & $2,040.30$ & 40 & 1 & 40 & 36 & 39 & 43 & 3 & 0 & -4 \\
\hline 7.00 & $2,098.20$ & 41 & 1 & 41 & 36 & 39 & 43 & 4 & 1 & -3 \\
\hline 8.00 & $2,500.70$ & 42 & 1 & 42 & 36 & 39 & 43 & 5 & 2 & -2 \\
\hline 9.00 & $2,499.90$ & 43 & 1 & 43 & 36 & 39 & 43 & 6 & 3 & -1 \\
\hline 10.00 & $2,238.60$ & 44 & 1 & 44 & 36 & 39 & 43 & 7 & 4 & 0 \\
\hline
\end{tabular}

